\title{
FURTHER EVIDENCE OF CHANGING STABILITY OF THE ATMOSPHERE
}

\section{SYLVIUS HARTWIG}

\section{Fachbereich Sicherheitstechnik der Bergischen Universität, D-42119 Wuppertal, Germany}

In a recent paper (Hartwig, ms.) I have shown that it is possible to understand and discuss the changing Austausch (i.e., exchange of air parcels between different atmospheric layers) between the stratosphere and troposphere by means of long-term measurement of series of spallation products. It is well known (Friend 1961; Müh et al. 1966; Hartwig et al. 1969) that there is a seasonal pattern in the ${ }^{7} \mathrm{Be}$ concentration of ground-level air with a maximum during May-June. This maximum is caused by enhanced exchange processes between the atmospheric compartments of the stratosphere and troposphere during this interval. Generally, those exchange processes are a consequence of stability and dynamics of the atmospheric compartments, which themselves result from, among other factors, the distribution of the heat sources in those compartments, namely the ground and the ozone layer.

Because of the growing importance of anthropogenic infrared-active gases in the atmosphere, it is to be expected that the relative importance of those original, naturally occurring heat sources will be of lesser significance, thus altering the Austausch. And indeed, it has been shown (Hartwig, ms.) by considering the ratio of the annual maximum and minimum during a $28-\mathrm{yr}$ period of ${ }^{7} \mathrm{Be}$ groundlevel concentration at Braunschweig, Germany $\left(10^{\circ} 33^{\prime} \mathrm{E}, 52^{\circ} 17^{\prime} \mathrm{N}\right)$ (Kolb 1992; Wershofen 1993), that there is a steady decline in that ratio, thus indicating alteration of atmospheric Austausch within the last three decades. This is commensurable with a growing concentration of infrared-active gases and the subsequent change of heat-source pattern in the atmosphere. To recognize such decline, however, it is necessary to utilize data sequences covering many years to detect the signal against the noise level.

In addition to the previously mentioned paper (Hartwig, ms.), I have discussed the maximum/minimum ${ }^{7} \mathrm{Be}$ ground-level concentration of another station at Skibotn, Sweden $\left(20^{\circ} 25^{\prime} \mathrm{E}, 69^{\circ} 20^{\prime} \mathrm{N}\right)$ (Kolb 1992), which has only a 15-yr duration, namely the time span between 1976 and 1990. Although this time span is considerably shorter than that of the Braunschweig data, there still is a distinct decline in the annual maximum/minimum ratio, showing a tendency toward decreasing $A$ ustausch between stratosphere and troposphere over those $15 \mathrm{yr}$. The two stations are situated in considerably different geographic locations, giving all the more significance to the agreement in tendency of atmospheric exchange pattern between stratosphere and troposphere. This agreement supports the view that anthropogenic infrared gases mitigate the relative importance of natural atmospheric heat sources and achieve a changing Austausch. Nevertheless, as expected, the signal discussed here is not so evident as in the case of the Braunschweig data, because the time span of the data series is shorter.

Figure 1 shows each year's ratio between the highest and lowest monthly concentration value. The figure includes three data sets for each year, calculated from the mean of one, two or three months, respectively. In addition, the compensating line is shown along with the corresponding equation. It can be clearly seen that with lower stratospheric influence (multiple monthly average value) the effect of changing Austausch is less distinct.

These data confirm the observation that the growing amount of anthropogenic infrared-active gases in the atmosphere changes not only climatic parameters but also short-term parameters such as the dynamic of the atmosphere and consequently exchange processes. 

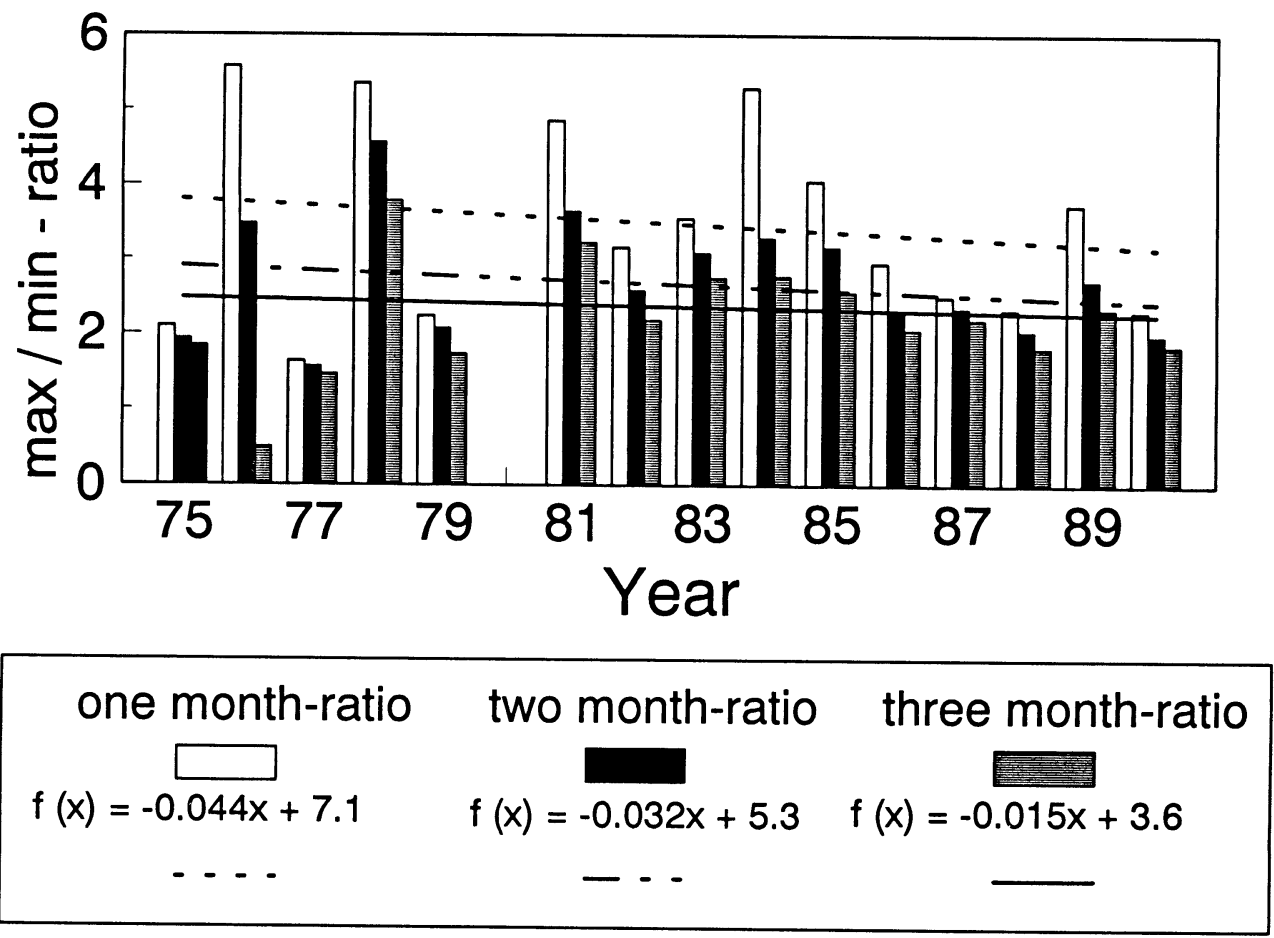

Fig. 1. $\mathrm{Max} / \mathrm{min}{ }^{7} \mathrm{Be}$ concentration ratio in ground-level air for averages of the highest to lowest monthly concentration value of each year, for one, two and three monthly means for the station Skibotn $\left(20^{\circ} 25^{\prime} \mathrm{E}, 69^{\circ} 20^{\prime} \mathrm{N}\right)$. Included in the figure is the linear compensating function (least square fit) and its value. With the help of the gradient of the function ( $x$-factor) it can be seen clearly that the decline of the ratio over the years is less distinct with multiple monthly averages because of the resulting smaller atmospheric influence.

\section{REFERENCES}

Hartwig, S. (ms.) Änderung des atmosphärischen Austauschverhaltens während der letzten Jahrzehnte. Submitted to Naturwissenschaften (Heidelberg).

Friend, D. P. 1961 High Altituude Sampling Program Report. Vol. 3.

Müh, H., Sittkus, A., Albrecht, G. and Hartwig, S. 1966 Radioaktive Isotope als Luftmassenindikatoren I. Zeitschrift für Naturforschung 21A(7): 1123-1127.

Hartwig, S. and Sittkus, A. 1968 Radioaktive Isotope als Luftmassenindikatoren II. Zeitschrift für Naturforschung 24A(6): 908-913.
Kolb, W. 1992 Aktivitätskonzentration von Radionukliden in der bodennahen Luft Norddeutschlands und Nordnorwegens im Zeitraum 1963-1990. PTB-Ra-29, Report der Physikalisch Technischen Bundesanstalt Braunschweig, March 1992.

Wershofen, H., and Arnold, D. 1993 Die Aktivitätskonzentrationen $\gamma$-strahlender Radionuklide im Staub der bodennahen Luft von Braunschweig und Berlin 1992. PTB-6.301-93-1, Report der Physikalisch Technischen Bundesanstalt Braunschweig, June 1993. 